\title{
Overweight and health problems of the lower extremities: osteoarthritis, pain and disability
}

\author{
A Tukker ${ }^{1,2}$, TLS Visscher $^{1,2}$ and HSJ Picavet ${ }^{1, *}$ \\ ${ }^{1}$ Centre for Prevention and Health Research, National Institute of Public Health and the Environment, \\ PO Box 1, 3720 BA Bilthoven, The Netherlands: ${ }^{2}$ Institute of Health Sciences, Vrije Universiteit, Amsterdam, \\ The Netherlands
}

Submitted 5 June 2007: Accepted 13 February 2008: First published online 22 April 2008

\begin{abstract}
Aim: To examine the association between overweight and health problems of the lower extremities, i.e. osteoarthritis (OA), pain and disability.

Methods: Cross-sectional data from the Dutch population-based Musculoskeletal Conditions \& Consequences Cohort (DMC3), comprising a random sample from the Dutch population aged $>25$ years ( $n$ 3664), were analysed using multivariate logistic regression. Overweight was defined as $\mathrm{BMI} \geq 25 \cdot 0 \mathrm{~kg} / \mathrm{m}^{2}$, moderate overweight as $25 \cdot 0 \mathrm{~kg} / \mathrm{m}^{2} \leq \mathrm{BMI}<30 \cdot 0 \mathrm{~kg} / \mathrm{m}^{2}$ and obesity as $\mathrm{BMI} \geq 30 \cdot 0 \mathrm{~kg} / \mathrm{m}^{2}$. Health problems of the lower extremities were: (i) self-reported OA of the hip or knee as told by a doctor; (ii) presence of self-reported chronic pain ( $>3$ months) of the lower extremities; and (iii) disabilities in mobility as measured by the Euroqol questionnaire (EQ-5D).

Results: Moderate overweight was associated with self-reported OA of the hip or knee $(\mathrm{OR}=1 \cdot 7 ; 95 \% \mathrm{CI} 1 \cdot 4,2 \cdot 1)$, chronic pain of the lower extremities at one or more location(s) $(\mathrm{OR}=1 \cdot 6 ; 95 \% \mathrm{CI} 1 \cdot 3,1 \cdot 9)$ and disability in mobility (OR $=1.7$; $95 \%$ CI $1 \cdot 4,2 \cdot 0)$. For obesity these odds were higher: $2 \cdot 8$ (95\% CI $2 \cdot 1,3 \cdot 7), 2 \cdot 5$ $(95 \%$ CI $1 \cdot 9,3 \cdot 2)$ and $3 \cdot 0(95 \%$ CI $2 \cdot 3,3 \cdot 9)$, respectively. Also, among those with OA, moderate overweight and obesity were associated with disability in mobility. Conclusion: There is a strong association between overweight/obesity and health problems of the lower extremities, i.e. OA, pain and disability. The increasing prevalence of overweight and obesity worldwide urges for public health action not only for diabetes and heart disease, but also OA.
\end{abstract}

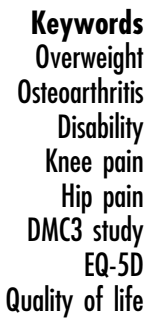

The prevalence of overweight has been increasing dramatically throughout the world during past decades. This trend has received a lot of attention in both the scientific and nonscientific literature. The majority of the literature showing the public health impact of overweight is on diabetes and CHD. Fewer studies show the impact of overweight on unhealthy life-years or its relationship with musculoskeletal disorders and disabilities such as impaired functioning in daily activities ${ }^{(1)}$ and work disability ${ }^{(2)}$.

Osteoarthritis (OA) is known to be one of the most prevalent joint disorders and is the leading cause of physical disability in the elderly ${ }^{(3,4)}$. Previous research has shown that overweight is the most important modifiable risk factor in the development of $\mathrm{OA}^{(5-7)}$. Owing to the ageing population in The Netherlands and the increasing rate of overweight ${ }^{(8,9)}$, it is expected that the prevalence of OA will increase greatly over the next few years ${ }^{(10)}$. One consequence of this trend is that OA-related health problems such as disability in mobility will also increase, as will the need for health-care facilities such as total knee replacement surgery and rehabilitation. With the ageing of the population physical dysfunctions are a major public health concern of the near future ${ }^{(11)}$, so we were interested not only in the role of overweight in OA but also in the role of overweight in OA-related disability.

The objectives of the present study were to examine the associations between overweight and health problems of the lower extremities, i.e. OA, pain and disability.

\section{Materials and methods}

\section{Study population}

Baseline data from the Dutch population-based Musculoskeletal Conditions \& Consequences Cohort (DMC3 study) were analysed. This study was executed in 1998 to examine physical disabilities and musculoskeletal conditions among the Dutch population. A random sample of 8000 men and women aged 25 years and over, stratified by 10-year age group and sex (equal numbers in each 
age-sex band), was taken from the population register of 1998. Data were obtained by a postal questionnaire. The net response rate of the DMC3 study was 46.9\% ( $n$ 3664). The response was slightly higher for women and for those aged $45-64$ years $^{(12,13)}$.

\section{Questionnaire structure}

The questionnaire contained general and health questions. Musculoskeletal disorders and pain in five different anatomical areas were recorded on pages with different colours $^{(12)}$. Data of the areas 'hip and knee' and 'ankle and foot' were used in the present analyses. Every coloured area started with a screening question: 'Did you have pain in this joint during the last twelve months?' Those who answered yes to this question were asked to answer all the questions of the relevant colour, focusing on the anatomical site, whether or not the pain still exists, the duration and severity of the pain, the course of the pain, self-reported causes, specific complaints and some consequences of the pain, e.g. health-care utilization or limitations in daily activities.

\section{Definitions}

\section{Overweight}

Participants were asked to report their height without shoes in centimetres and to report their weight without clothes in kilograms, from which BMI $\left(\mathrm{kg} / \mathrm{m}^{2}\right)$ was calculated. Overweight was defined as $\mathrm{BMI} \geq 25 \cdot 0 \mathrm{~kg} / \mathrm{m}^{2}$, moderate overweight as $25 \cdot 0 \mathrm{~kg} / \mathrm{m}^{2} \leq \mathrm{BMI}<30 \cdot 0 \mathrm{~kg} / \mathrm{m}^{2}$ and obesity was defined as BMI $\geq 30 \cdot 0 \mathrm{~kg} / \mathrm{m}^{2}$. We did not distinguish underweight, $\mathrm{BMI}<18.5 \mathrm{~kg} / \mathrm{m}^{2}$, because numbers were very low ( $n 51,1 \cdot 4 \%$ ). We excluded those with missing data for weight or height ( $n 119,3 \cdot 2 \%$ ).

\section{Health problems of the lower extremities}

In the present study, health problems of the lower extremities were classified according to the following definitions.

1. OA of the hip or knee: A positive answer to the question 'Have you ever been told by a doctor that you have osteoarthritis?' or 'Are you in treatment for osteoarthritis by a general practitioner or medical specialist?' Knee and hip OA were distinguished separately. Given the structure of the questionnaire we assumed that not ticking 'yes/no' to a specific disease implied not having that specific disease ( $n$ 549). Those with missing values either had missing ticks for all questions on musculoskeletal diseases ( $n$ 217) or only ticked 'yes' for those diseases the person had ( $n$ 332). So not ticking 'yes/no' implied 'not applicable', i.e. not having the disease.

2. Chronic pain in the lower extremities: Those who reported pain of the lower extremities, i.e. hip, knee, ankle or foot, with duration of longer than 3 months.

3. OA and chronic pain: Respondents with OA of the hip or knee who also reported chronic pain in at least one location of the lower extremities.
4. OA or chronic pain: Participants with either OA of the hip or knee or chronic pain reported in at least one location of the lower extremities.

Disabilities were reported according to the Euroqol questionnaire $(\mathrm{EQ}-5 \mathrm{D})^{(14)}$. The EQ-5D consists of five questions with the following dimensions: mobility, selfcare, usual activities, pain and anxiety/depression. Each question contains three response categories ${ }^{(15)}$ : 'no problems with' $(=1)$; 'some problems with' $(=2)$; 'many problems with or impossible to...' $(=3)$. Participants were coded disabled when they marked the answers ' 2 ' or ' 3 '. Missing values were assumed to indicate no problems (missing one of the five dimensions: $n$ 200, $5 \cdot 5 \%$ ).

\section{Statistical analyses}

The associations between OA of the hip or knee, chronic pain, disabilities and overweight were studied by the use of multiple logistic regression analysis, with adjustment for potential confounding by sex and age. The Statistical Package for the Social Science statistical software package version 12.0 (SPSS Inc., Chicago, IL, USA) was used for the computations. The characteristics of the study population are presented herein without standardization. This can result in differences with respect to former data published with standardization.

\section{Results}

Overweight affected $44.9 \%$ of the respondents and $9.3 \%$ were obese. Almost $30 \%$ of the population reported chronic pain at one or more location(s) of the lower extremities or self-reported OA. A quarter of the sample reported disability in mobility (Table 1 ).

Overweight was associated with a higher prevalence of health problems of the lower extremities, regardless of definition (Table 2). There also appeared to be a dose-response relationship between the degree of overweight and the presence of OA, pain and disabilities. For instance, for OA or chronic pain, the OR for moderate overweight was $1.6(95 \%$ CI $1.4,1.9)$ and for obesity it was $2 \cdot 6(95 \%$ CI $2 \cdot 1,3 \cdot 4)$. The association seemed particularly strong between obesity and OA of the knee $(\mathrm{OR}=3 \cdot 1 ; 95 \% \mathrm{CI} 2 \cdot 4,4 \cdot 2)$ and between obesity and chronic knee pain $(\mathrm{OR}=3 \cdot 1 ; 95 \%$ CI $2 \cdot 3,4 \cdot 1)$. In addition, we analysed the role of BMI as a continuous variable. For each unit increase in BMI respondents were $8 \%$ more likely to report OA or chronic pain.

Overweight and obesity were also associated with a higher prevalence of disability, particularly with disability in mobility (moderate overweight: $\mathrm{OR}=1 \cdot 7 ; 95 \% \mathrm{CI} 1 \cdot 4$, $2 \cdot 0$; obesity: $\mathrm{OR}=3 \cdot 0,95 \% \mathrm{CI} 2 \cdot 3,3 \cdot 9$ ) and pain (moderate overweight: $\mathrm{OR}=1 \cdot 4 ; 95 \% \mathrm{CI} 1 \cdot 2,1 \cdot 7$; obesity: $\mathrm{OR}=1 \cdot 7,95 \%$ CI $1 \cdot 3,2 \cdot 2$ ) (Table 2 ). Also among those with self-reported OA or pain, overweight and obesity were associated with disability in mobility $(\mathrm{OR}=1 \cdot 3$; 
Table 1 Characteristics of the study population: the Musculoskeletal Conditions \& Consequences Cohort (DMC3 study), The Netherlands, 1998

\begin{tabular}{|c|c|c|c|}
\hline Characteristic & $\begin{array}{c}\text { Total } \\
(n \text { 3664) }\end{array}$ & $\begin{array}{c}\text { Men } \\
(n \text { 1640) }\end{array}$ & $\begin{array}{l}\text { Women } \\
\text { (n 2024) }\end{array}$ \\
\hline Sex distribution (\%) & - & $44 \cdot 8$ & $55 \cdot 2$ \\
\hline Mean age (years) & $54 \cdot 6$ & $56 \cdot 1$ & $53 \cdot 3$ \\
\hline Mean weight $(\mathrm{kg})$ & $74 \cdot 1$ & $80 \cdot 3$ & 68.9 \\
\hline Mean height $(\mathrm{cm})$ & $171 \cdot 8$ & $178 \cdot 4$ & $166 \cdot 5$ \\
\hline Mean BMI $\left(\mathrm{kg} / \mathrm{m}^{2}\right)$ & $25 \cdot 0$ & $25 \cdot 3$ & $24 \cdot 9$ \\
\hline \multicolumn{4}{|l|}{ Age distribution (\%) } \\
\hline $25-44$ years & $32 \cdot 1$ & $29 \cdot 1$ & $34 \cdot 6$ \\
\hline $45-64$ years & $36 \cdot 8$ & $36 \cdot 3$ & $37 \cdot 2$ \\
\hline$\geq 65$ years & $31 \cdot 1$ & $34 \cdot 6$ & $28 \cdot 3$ \\
\hline Overweight* $(\%)$ & $44 \cdot 9$ & $49 \cdot 2$ & $41 \cdot 3$ \\
\hline Moderate overweight* (\%) & $35 \cdot 6$ & $41 \cdot 8$ & $30 \cdot 4$ \\
\hline Obesity $^{*}(\%)$ & $9 \cdot 3$ & $7 \cdot 4$ & $10 \cdot 9$ \\
\hline \multicolumn{4}{|l|}{ Osteoarthritis (OA) (\%) } \\
\hline Hip & $9 \cdot 7$ & $6 \cdot 5$ & $12 \cdot 3$ \\
\hline Knee & $15 \cdot 0$ & $13 \cdot 0$ & $16 \cdot 5$ \\
\hline Hip or knee & $19 \cdot 4$ & $16 \cdot 0$ & $22 \cdot 2$ \\
\hline \multicolumn{4}{|l|}{ Chronic pain (\%) } \\
\hline Hip & $8 \cdot 8$ & $6 \cdot 0$ & $11 \cdot 1$ \\
\hline Knee & $12 \cdot 8$ & $10 \cdot 6$ & $14 \cdot 6$ \\
\hline Ankle & $3 \cdot 9$ & $2 \cdot 9$ & $4 \cdot 7$ \\
\hline Feet & $5 \cdot 8$ & $4 \cdot 8$ & $6 \cdot 7$ \\
\hline \multicolumn{4}{|c|}{$\begin{array}{l}\text { Number of locations of chronic } \\
\text { pain (\%) }\end{array}$} \\
\hline$\geq 1$ location & $21 \cdot 1$ & $17 \cdot 0$ & $24 \cdot 4$ \\
\hline$\geq 2$ locations & $7 \cdot 3$ & $5 \cdot 3$ & $8 \cdot 9$ \\
\hline 4 locations & 0.9 & 0.5 & $1 \cdot 2$ \\
\hline $\mathrm{OA}$ and chronic paint (\%) & $10 \cdot 1$ & $7 \cdot 2$ & $12 \cdot 6$ \\
\hline OA or chronic pain $(\%)$ & $29 \cdot 8$ & $25 \cdot 4$ & 33.3 \\
\hline \multicolumn{4}{|c|}{ Euroqol dimensions (EQ-5D) (\%) } \\
\hline Mobility & $25 \cdot 1$ & $22 \cdot 6$ & $27 \cdot 2$ \\
\hline Self-care & $5 \cdot 4$ & $5 \cdot 0$ & $5 \cdot \overline{7}$ \\
\hline Usual activities & $24 \cdot 7$ & $19 \cdot 7$ & $28 \cdot 8$ \\
\hline Pain & $48 \cdot 6$ & $42 \cdot 9$ & $53 \cdot 4$ \\
\hline Anxiety/depression & $19 \cdot 0$ & $15 \cdot 3$ & $22 \cdot 0$ \\
\hline
\end{tabular}

${ }^{*}$ Overweight defined as $\mathrm{BMI} \geq 25.0 \mathrm{~kg} / \mathrm{m}^{2}$, moderate overweight as 25.0 $\mathrm{kg} / \mathrm{m}^{2} \leq \mathrm{BMI}<30.0 \mathrm{~kg} / \mathrm{m}^{2}$ and obesity as $\mathrm{BMI} \geq 30.0 \mathrm{~kg} / \mathrm{m}^{2} ; 119$ participants had missing data for weight or height.

tParticipants who reported OA of the hip or knee and at least one location of chronic pain.

‡Participants who reported OA of the hip or knee or at least one location of chronic pain.

$95 \%$ CI $1 \cdot 0,1 \cdot 8$ for moderate overweight; OR $=2 \cdot 4 ; 95 \%$ CI $1 \cdot 6,3 \cdot 6$ for obesity) (Table 3 ). Among those with selfreported OA or pain there was no association of overweight with any of the other EQ-5D dimensions.

The data were also analysed by age group and sex. No differences in patterns were found by age group but some differences were found between men and women (data not shown): overweight was more strongly associated with knee OA in women than in men and moderate overweight was more strongly associated with OA of the hip among men. Among those with OA, moderate overweight was more associated with disability in mobility in men than in women.

\section{Discussion}

The present study shows that overweight is associated with OA and that overweight increases the risk of disability in mobility, both in the general population and among those with OA. The study also reveals that overweight is associated with both hip and knee OA, the association being strongest for knee OA.

These associations are comparable to those found in previous cross-sectional, cohort and case-control studies. For OA of the knee, earlier published data are summarized in Table $4^{(5-7,16-27)}$, where it can be seen that the range in odds or relative risk is $1 \cdot 9-6 \cdot 8$. In the present study we found OR of $1 \cdot 5$ (moderate overweight) and $3 \cdot 1$ (obesity) for OA of the knee and OR of $1 \cdot 8$ (moderate overweight) and $3 \cdot 1$ (obesity) for chronic pain of the knee. The descriptions in Table 4 show that the definitions of both knee OA and BMI categories differed substantially between the studies, as did the study populations and methods of analysis. However, it is clear is that both moderate overweight and obesity have an impact on knee OA, with higher associations with increasing BMI.

The OR that we found for OA of the hip ( 1.8 for moderate overweight, $2 \cdot 0$ for obesity) and chronic pain of the hip ( 1.5 for moderate overweight, 1.4 for obesity) are also in line with published results: Lievense et al. presented odds in the range of $1 \cdot 2-5 \cdot 2$ in a review on overweight and hip $\mathrm{OA}^{(3)}$. They reported that the association between obesity and hip OA was stronger in studies in which the diagnosis was based not only on radiographic criteria but also on joint symptoms. Recent additional studies by Flugsrud et al. ${ }^{(28,29)}$ and Karlson et $a l^{(30)}$ also showed only a weak association between overweight and radiographic hip OA. Felson et al. ${ }^{(31)}$ reported that it is preferable to define OA by the presence of symptoms and radiographic change; however, they also stated that, especially for knee OA, some studies using symptom-based definitions of OA have yielded roughly similar results to studies using radiographic evidence. In the present study we used data based on hip pain and self-reported hip OA. Owing to our public health point of view we followed the advice from a working group of experts that 'symptomatic arthritis rather than radiographic evidence of arthritis should be used to measure prevalence. Symptomatic includes both self-reported arthritis as well as reported pain in the joints ${ }^{,(32)}$. In addition there is also some evidence that a substantial proportion of those persons with hip or knee pain as identified with a questionnaire have radiographic $\mathrm{OA}^{(33,34)}$

It is known that, compared with other chronic diseases, people with OA of the hip or knee report the worst quality of life among people with musculoskeletal diseases ${ }^{(14)}$. Overweight and obesity play a role in this relationship: moderate overweight and in particular obesity were associated with disabilities in the present study, both among those with and without OA. This is also reported in previous studies ${ }^{(22,35-38)}$. Schouten et al. reported that disabilities could partly be due to cartilage 
Table 2 Associations of overweight/obesity with osteoarthritis (OA)-related health problems and disability in the total population: the Musculoskeletal Conditions \& Consequences Cohort (DMC3 study), The Netherlands, 1998

\begin{tabular}{|c|c|c|c|c|}
\hline & \multicolumn{2}{|c|}{ Moderate overweight* ( $n$ 1244) } & \multicolumn{2}{|c|}{ Obesityt ( $n$ 325) } \\
\hline & OR & $95 \% \mathrm{Cl}$ & OR & $95 \% \mathrm{Cl}$ \\
\hline \multicolumn{5}{|l|}{ OA } \\
\hline Hip & $1 \cdot 8$ & $1 \cdot 4,2 \cdot 3$ & $2 \cdot 0$ & $1 \cdot 4,3 \cdot 0$ \\
\hline Knee & $1 \cdot 5$ & $1 \cdot 2,1 \cdot 9$ & $3 \cdot 1$ & $2 \cdot 4,4 \cdot 2$ \\
\hline Hip or knee & $1 \cdot 7$ & $1 \cdot 4,2 \cdot 1$ & $2 \cdot 8$ & $2 \cdot 1,3 \cdot 7$ \\
\hline \multicolumn{5}{|l|}{ Chronic pain } \\
\hline Hip & $1 \cdot 5$ & $1 \cdot 2,2 \cdot 0$ & $1 \cdot 4$ & $0 \cdot 9,2 \cdot 1$ \\
\hline Knee & $1 \cdot 8$ & $1 \cdot 5,2 \cdot 3$ & $3 \cdot 1$ & $2 \cdot 3,4 \cdot 1$ \\
\hline Ankle & $1 \cdot 7$ & $1 \cdot 2,2 \cdot 5$ & $3 \cdot 1$ & $1 \cdot 9,4 \cdot 9$ \\
\hline Feet & $1 \cdot 3$ & $0 \cdot 9,1 \cdot 8$ & $2 \cdot 2$ & $1 \cdot 5,3 \cdot 4$ \\
\hline \multicolumn{5}{|c|}{ Number of locations of chronic pain } \\
\hline$\geq 1$ location & $1 \cdot 6$ & $1 \cdot 3,1 \cdot 9$ & $2 \cdot 5$ & $1 \cdot 9,3 \cdot 2$ \\
\hline$\geq 2$ locations & $1 \cdot 6$ & $1 \cdot 2,2 \cdot 2$ & $3 \cdot 0$ & $2 \cdot 0,4 \cdot 3$ \\
\hline 4 locations & $2 \cdot 8$ & $1 \cdot 2,6 \cdot 5$ & $2 \cdot 4$ & $0 \cdot 7,7 \cdot 8$ \\
\hline OA and chronic pain & $1 \cdot 8$ & $1 \cdot 4,2 \cdot 4$ & $2 \cdot 8$ & $2 \cdot 0,3 \cdot 9$ \\
\hline OA or chronic pain§ & $1 \cdot 6$ & $1 \cdot 4,1 \cdot 9$ & $2 \cdot 6$ & $2 \cdot 1,3 \cdot 4$ \\
\hline \multicolumn{5}{|l|}{ Disability\| } \\
\hline Mobility & $1 \cdot 7$ & $1 \cdot 4,2 \cdot 0$ & $3 \cdot 0$ & $2 \cdot 3,3 \cdot 9$ \\
\hline Self-care & $0 \cdot 9$ & $0 \cdot 6,1 \cdot 3$ & $1 \cdot 7$ & $1 \cdot 0,2 \cdot 7$ \\
\hline Usual activities & $1 \cdot 1$ & $0 \cdot 9,1 \cdot 3$ & $1 \cdot 7$ & $1 \cdot 3,2 \cdot 2$ \\
\hline Pain & $1 \cdot 4$ & $1 \cdot 2,1 \cdot 7$ & $1 \cdot 7$ & $1 \cdot 3,2 \cdot 2$ \\
\hline Anxiety/depression & $1 \cdot 1$ & $0 \cdot 9,1 \cdot 3$ & $1 \cdot 2$ & $0.9,1 \cdot 6$ \\
\hline
\end{tabular}

${ }^{*}$ Moderate overweight defined as $25 \cdot 0 \mathrm{~kg} / \mathrm{m}^{2} \leq \mathrm{BMI}<30 \cdot 0 \mathrm{~kg} / \mathrm{m}^{2}$.

tObesity defined as $\mathrm{BMI} \geq 30.0 \mathrm{~kg} / \mathrm{m}^{2}$.

$\ddagger$ Participants who reported OA of the hip or knee and at least one location of chronic pain.

§Participants who reported OA of the hip or knee or at least one location of chronic pain.

॥Disability according to Euroqol dimensions (EQ-5D).

Table 3 Effect of overweight/obesity on associations of osteoarthritis (OA)-related health problems with disability among participants with OA: the Musculoskeletal Conditions \& Consequences Cohort (DMC3 study), The Netherlands, 1998

\begin{tabular}{|c|c|c|c|c|c|}
\hline \multirow[b]{2}{*}{ OA-related health problem } & \multirow[b]{2}{*}{ Disability* } & \multicolumn{2}{|c|}{ Moderate overweightt ( $n$ 1244) } & \multicolumn{2}{|c|}{ Obesitył (n 325) } \\
\hline & & OR & $95 \% \mathrm{Cl}$ & OR & $95 \% \mathrm{Cl}$ \\
\hline \multirow[t]{5}{*}{ OA of the hip or knee } & Mobility & $1 \cdot 4$ & $1 \cdot 0,2 \cdot 0$ & $2 \cdot 9$ & $1 \cdot 7,4 \cdot 9$ \\
\hline & Self-care & 0.6 & $0 \cdot 4,1 \cdot 0$ & $0 \cdot 8$ & $0.4,1.5$ \\
\hline & Usual activities & $1 \cdot 0$ & $0 \cdot 7,1 \cdot 4$ & 1.5 & $1 \cdot 0,2 \cdot 4$ \\
\hline & Pain & $1 \cdot 1$ & $0 \cdot 8,1 \cdot 7$ & 1.9 & $1 \cdot 0,3 \cdot 5$ \\
\hline & Anxiety & $1 \cdot 1$ & $0 \cdot 7,1 \cdot 6$ & $1 \cdot 0$ & $0 \cdot 6,1 \cdot 7$ \\
\hline \multirow[t]{5}{*}{ Chronic pain at $\geq 1$ location } & Mobility & $1 \cdot 3$ & $0.9,1.9$ & $2 \cdot 3$ & $1 \cdot 4,3 \cdot 8$ \\
\hline & Self-care & $0 \cdot 6$ & $0 \cdot 4,1 \cdot 1$ & $0 \cdot 8$ & $0.4,1.6$ \\
\hline & Usual activities & $1 \cdot 2$ & $0.8,1.6$ & $1 \cdot 6$ & $1 \cdot 0,2 \cdot 6$ \\
\hline & Pain & $1 \cdot 0$ & $0 \cdot 7,1 \cdot 6$ & $1 \cdot 1$ & $0.6,1.9$ \\
\hline & Anxiety & $1 \cdot 2$ & $0 \cdot 8,1 \cdot 7$ & $1 \cdot 2$ & $0.7,1.9$ \\
\hline \multirow[t]{5}{*}{ OA and chronic pain§ } & Mobility & $1 \cdot \overline{3}$ & $0 \cdot 8,2 \cdot 2$ & $3 \cdot 0$ & $1 \cdot 4,6 \cdot 7$ \\
\hline & Self-care & 0.5 & $0.3,0.9$ & 0.5 & $0 \cdot 2,1 \cdot 3$ \\
\hline & Usual activities & $1 \cdot 1$ & $0 \cdot 7,1 \cdot 8$ & $1 \cdot 7$ & $0.9,3 \cdot 2$ \\
\hline & Pain & $0 \cdot 7$ & $0 \cdot 3,1 \cdot 3$ & 0.9 & $0 \cdot 3,2 \cdot 4$ \\
\hline & Anxiety & 0.9 & $0.5,1.5$ & 0.9 & $0.5,1 \cdot 7$ \\
\hline \multirow[t]{5}{*}{ OA or chronic pain $\|$} & Mobility & $1 \cdot 3$ & $1 \cdot 0,1 \cdot 8$ & $2 \cdot 4$ & $1 \cdot 6,3 \cdot 6$ \\
\hline & Self-care & 0.7 & $0 \cdot 4,1 \cdot 1$ & 0.9 & $0.5,1.7$ \\
\hline & Usual activities & $1 \cdot 0$ & $0.8,1 \cdot 3$ & $1 \cdot 5$ & $1 \cdot 0,2 \cdot 2$ \\
\hline & Pain & $1 \cdot 2$ & $0.9,1.6$ & 1.5 & $0.9,2.4$ \\
\hline & Anxiety & $1 \cdot 2$ & $0 \cdot 9,1 \cdot 7$ & $1 \cdot 2$ & $0.8,1 \cdot 8$ \\
\hline
\end{tabular}

${ }^{*}$ Disability according to Euroqol dimensions (EQ-5D).

tModerate overweight defined as $25 \cdot 0 \mathrm{~kg} / \mathrm{m}^{2} \leq \mathrm{BMI}<30 \cdot 0 \mathrm{~kg} / \mathrm{m}^{2}$.

$\ddagger$ Obesity defined as $\mathrm{BMI} \geq 30 \cdot 0 \mathrm{~kg} / \mathrm{m}^{2}$.

\$Participants who reported OA of the hip or knee and at least one location of chronic pain.

$\|$ Participants who reported OA of the hip or knee or at least one location of chronic pain.

loss, which is known to be strongly associated with knee $\mathrm{OA}$ and overweight ${ }^{(36)}$. Peltonen et $a l^{(37)}$ concluded that obese subjects have more problems with work-restricting musculoskeletal pain than non-obese subjects. In a review Zamboni et al. ${ }^{(38)}$ found that body weight and BMI play a significant role in non-fatal physical disability in the elderly. In addition to these findings, it is meaningful to examine whether weight loss might prevent OA or delay 
Table 4 The association of osteoarthritis $(\mathrm{OA})$ of the knee with overweight or obesity: results from some previous studies

\begin{tabular}{|c|c|c|c|c|}
\hline Author & Population & Assessment of knee OA & Adjusted for & Results* \\
\hline $\begin{array}{l}\text { Cross-sectional studies } \\
\text { Anderson \& Felson } \\
(1988)^{(16)}\end{array}$ & $\begin{array}{l}\text { NHANES I: civilian, non- } \\
\text { institutionalized population of US } \\
\text { adults aged } 35-74 \text { years, } n 5193\end{array}$ & $\begin{array}{l}\text { Minimal grade } 2 \text { of } X \text {-ray diagnosed } \\
\text { OA, with or without knee pain } \\
>1 \text { month: } n 315 \text {, prev }=5 \%\end{array}$ & $\begin{array}{l}\text { Race, 10-year age } \\
\text { group }\end{array}$ & $\begin{array}{l}\text { Males } \\
25 \cdot 0<\mathrm{BMI} \leq 30 \cdot 0: \mathrm{RR}=1 \cdot 69(1 \cdot 03,2 \cdot 80) \\
30 \cdot 0<\mathrm{BMI} \leq 35 \cdot 0: \mathrm{RR}=4 \cdot 78(2 \cdot 77,8 \cdot 27) \\
\mathrm{BMI}>35 \cdot 0: \mathrm{RR}=4 \cdot 45(1 \cdot 77,11 \cdot 18) \\
\text { Females } \\
25 \cdot 0<\mathrm{BMI} \leq 30 \cdot 0: \mathrm{RR}=1 \cdot 89(1 \cdot 24,2 \cdot 87) \\
30 \cdot 0<\mathrm{BMI} \leq 35 \cdot 0: \mathrm{RR}=3 \cdot 87(2 \cdot 63,5 \cdot 68) \\
\mathrm{BMI}>35 \cdot 0: \mathrm{RR}=7 \cdot 37(5 \cdot 15,10 \cdot 53)\end{array}$ \\
\hline $\begin{array}{l}\text { Hochberg et al. } \\
(1995)^{(7)}\end{array}$ & $\begin{array}{l}\text { Baltimore Longitudinal Study of } \\
\text { Aging: adults aged } \geq 40 \text { years, with } \\
\text { radiographs of both knees between } \\
1984 \text { and } 1991, n 740\end{array}$ & $\begin{array}{l}\text { Minimal grade } 2 \text { of radiographic OA: } \\
\text { males, } n 169, \text { prev }=36 \cdot 3 \% \\
\text { females, } n 99, \text { prev }=36 \cdot 0 \%\end{array}$ & Age & 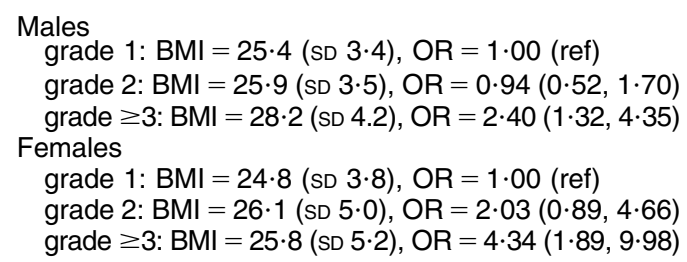 \\
\hline
\end{tabular}

\section{Sowers et al. $(1996)^{(17)}$ \\ Michigan Bone Health Study: Caucasian woman aged 24-45 years in 1992, $n 573$}

Sowers et al. $(2000)^{(18)}$

Cimmino et al. $(2005)^{(19)}$

\section{Michigan Bone Health Study and} SWAN study: pre- and

perimenopausal woman in southeast Michigan aged $27-53$ years $(n 1053)$ and $\geq 40$ years $(n$ 831)

Italian patients with $\mathrm{OA}$ of hip, hand or knee, aged 50-104 years, enrolled by general practitioners, $n 25589$

\section{Radiographic $\mathrm{OA} \geq$ grade 2 :} prev $=3.6 \%$

Minimal grade 2 of radiographic $\mathrm{OA}$ : $\geq 40$ years, prev $=14.2 \%$; $<40$ years, prev $=1.4 \%$

Diagnosed according to the American College of Rheumatology clinical criteria: OA, $n 12827$, prev $=54 \%$
Various confounders

Age, race, injury, smoking

Gender, age, BMI, OA duration, multiple joint involvement, comorbidities
BMI significant in predicting an increase in evaluation score of OA:

$\mathrm{OR}=1 \cdot 10(1 \cdot 04,1 \cdot 17)$ for 1 -unit increase in BMI

Among knee OA, BMI values much higher. $14 \%$ increase in knee OA with 1-unit increase in BMI.

10-unit BMI difference in those with and without knee $\mathrm{OA}$ in overall population

$\geq 40$ years: median $\mathrm{BMI}=37 \cdot 1$ (with $\mathrm{OA}$ ) v. $28 \cdot 4$ (without OA)

Prev of obesity and knee OA

$19 \%$ men, $30 \%$ women

Experience of intense pain ( $>60 \mathrm{~mm}$ VAS) with knee OA women: OR $=1 \cdot 24(1 \cdot 15,1.34)$

Intense pain of knee

$30 \cdot 0 \leq \mathrm{BMI}: \mathrm{OR}=1 \cdot 40(1 \cdot 28,1.53)$ 


\begin{tabular}{|c|c|c|c|c|}
\hline Author & Population & Assessment of knee OA & Adjusted for & Results* \\
\hline \multicolumn{5}{|l|}{ Cohort studies } \\
\hline $\begin{array}{l}\text { Felson et al. } \\
(1988)^{(20)}\end{array}$ & $\begin{array}{l}\text { Framingham Heart Study Cohort: } \\
\text { 1948-1951, mean age } 37 \text { years, } \\
n \text { 1420; follow-up 1983-1985, } \\
\text { mean age } 73 \text { years, } n 1420\end{array}$ & $\begin{array}{l}\text { Radiographic, } n 468 \\
\text { Severe, } n 223 \\
\text { Symptomatic, } n 135\end{array}$ & $\begin{array}{l}\text { Age, diabetes, uric acid } \\
\text { level, physical activity }\end{array}$ & $\begin{array}{l}\text { MRW quintile } 1,2 \text { and } 3: \mathrm{RR}=1 \cdot 00 \text { (ref) } \\
\text { Males } \\
\quad \text { quintile } 4 \text { (2nd heaviest): } \mathrm{RR}=1 \cdot 00(0 \cdot 71,1 \cdot 42) \\
\text { quintile } 5 \text { (heaviest): } \mathrm{RR}=1 \cdot 54(1 \cdot 18,2 \cdot 02) \\
\text { Females } \\
\quad \text { quintile } 4: \mathrm{RR}=1 \cdot 38(1 \cdot 08,1 \cdot 78) \\
\quad \text { quintile } 5: \mathrm{RR}=1 \cdot 93(1 \cdot 56,2 \cdot 37) \\
\text { A strong association between being overweight or } \\
\text { obese in } 1948-1952 \text { and having knee OA } 36 \text { years } \\
\text { later }\end{array}$ \\
\hline $\begin{array}{l}\text { Manninen et al. } \\
(1996)^{(21)}\end{array}$ & $\begin{array}{l}\text { Finnish farmers aged 40-64 years: } \\
\text { 1979-1980, } n \text { 6647; follow-up, } \\
n 965\end{array}$ & $\begin{array}{l}\text { Primaire OA based on radiographic } \\
\text { changes grade } 3 \text { or } 4 \text { : males, } n 18 \\
\text { females, } n 108\end{array}$ & Age & $\begin{array}{l}\text { RR of disability, unilateral or bilateral OA } \\
\text { per } \mathrm{SD}\left(3 \cdot 8 \mathrm{~kg} / \mathrm{m}^{2}\right) \text { of } \mathrm{BMI}: \mathrm{RR}=1.35(1 \cdot 24,1 \cdot 47) \\
\text { Unilateral or bilateral OA } \\
\text { females: } \mathrm{RR}=4.92(2 \cdot 99,8 \cdot 11) \\
\text { males: } \mathrm{RR}=1.00 \text { (ref) }\end{array}$ \\
\hline $\begin{array}{l}\text { Felson et al. } \\
(1997)^{(22)}\end{array}$ & $\begin{array}{l}\text { Framingham OA study: population } \\
\text { without knee OA in 1983-1985, } \\
\text { mean age } 70.5 \text { years, } n \text { 598; at } \\
\text { follow-up in } 1992-1993,93 \\
\text { developed knee OA }\end{array}$ & Minimal grade 2 of radiographic $O A$ & $\begin{array}{l}\text { Age, sex, BMI, weight } \\
\text { change, smoking, } \\
\text { injury, } \\
\text { chondrocalcinoses, } \\
\text { hand OA, physical } \\
\text { activity }\end{array}$ & $\begin{array}{l}\text { Higher baseline } \mathrm{BMI} \text { increased the risk of OA } \\
\mathrm{OR}=1 \cdot 6(1 \cdot 2,2 \cdot 2) \text { per } 5 \text {-unit increase } \\
\text { males: } \mathrm{OR}=1 \cdot 0(0 \cdot 5,2 \cdot 1) \\
\text { females: } \mathrm{OR}=1 \cdot 8(1 \cdot 2,2 \cdot 6)\end{array}$ \\
\hline $\begin{array}{l}\text { Gelber et al. } \\
(1999)^{(23)}\end{array}$ & $\begin{array}{l}\text { Male medical students at Johns } \\
\text { Hopkins University aged } 23 \text { (SD 2) } \\
\text { years in 1948-1964, } n 1180 ; \\
\text { at follow-up 1995, } n 52\end{array}$ & $\begin{array}{l}\text { Self-reported by questionnaire; } \\
\text { symptom-related questions and/or } \\
\text { radiographs, } n 43\end{array}$ & $\begin{array}{l}\text { Year of birth, physical } \\
\text { activity, knee injury }\end{array}$ & $\begin{array}{l}\text { Incidence of knee OA strongly associated with } \mathrm{BMI} \text { at } \\
\text { age } 20-39 \\
\text { Age } 20-29 \text { years } \\
22 \cdot 8 \leq \mathrm{BMl}<24 \cdot 7: \mathrm{RR}=1 \cdot 4(0 \cdot 7,3 \cdot 0) \\
24 \cdot 7 \leq \mathrm{BMl}: \mathrm{RR}=3 \cdot 5(1 \cdot 8,6 \cdot 8) \\
\text { Age } 30-39 \text { years } \\
22 \cdot 8 \leq \mathrm{BMl}<24 \cdot 7: \mathrm{RR}=2 \cdot 5(1 \cdot 0,6 \cdot 3) \\
24 \cdot 7 \leq \mathrm{BMl}: \mathrm{RR}=3 \cdot 7(1 \cdot 5,9 \cdot 0)\end{array}$ \\
\hline $\begin{array}{l}\text { Miranda et al. } \\
(2002)^{(24)}\end{array}$ & $\begin{array}{l}\text { Employees of a Finnish forestry } \\
\text { company: 1994, } n \text { 3312; follow-up } \\
\text { 1995, } n 2984\end{array}$ & $\begin{array}{l}\text { Pain of knee: severe, } n 333,12 \% \text {; } \\
\quad \text { mild, } n 316,11 \% \text {; incidence, } \\
n 2122,77 \%\end{array}$ & $\begin{array}{l}\text { Age, sex, overweight, } \\
\text { smoking and knee } \\
\text { injuries }\end{array}$ & $\begin{array}{l}\text { Incidence of knee pain } \\
23 \cdot 0>\text { BMI: OR }=1 \cdot 0 \text { (ref) } \\
23 \cdot 0 \leq \mathrm{BMI} \leq 25 \cdot 9: \mathrm{OR}=1 \cdot 2(0 \cdot 7,2 \cdot 0) \\
26 \cdot 0 \leq \mathrm{BMI} \leq 28 \cdot 9: \mathrm{OR}=1 \cdot 9(1 \cdot 2,3 \cdot 2) \\
29 \cdot 0 \leq \mathrm{BMI}: \mathrm{OR}=1 \cdot 8(1 \cdot 0,3 \cdot 3)\end{array}$ \\
\hline
\end{tabular}




\begin{tabular}{|c|c|c|c|c|}
\hline Author & Population & Assessment of knee OA & Adjusted for & Results* \\
\hline $\begin{array}{l}\text { Felson et al. } \\
(1992)^{(25)}\end{array}$ & $\begin{array}{l}\text { Woman who participated in } \\
\text { Framingham study: 1983-1985, } \\
\text { n 796; follow-up, } n 64\end{array}$ & $\begin{array}{l}\text { Symptomatic knee OA (knee } \\
\text { symptoms plus radiographically } \\
\text { confirmed OA) }\end{array}$ & $\begin{array}{l}\text { Age, baseline BMI, } \\
\text { knee injury, physical } \\
\text { activity level, } \\
\text { smoking status, } \\
\text { education level }\end{array}$ & $\begin{array}{l}\text { Decrease of } \geq 2 \mathrm{BMI} \text { units }(\geq 5 \mathrm{~kg}) 10 \text { years before } \\
\text { current examination } \\
\text { OR }=0 \cdot 46(0 \cdot 24,0 \cdot 86) \\
\text { Among those with baseline } \mathrm{BMI} \geq 25 \\
\text { OR }=0.41 \text { for decreasing } 2 \text { units of BMI }\end{array}$ \\
\hline Jinks et al. (2006) & $\begin{array}{l}\text { Persons ( }>50 \text { years) registered at } 3 \\
\text { general practices in UK: } 2000 \\
n 6772 \text {; follow-up 2003, } n 4317\end{array}$ & $\begin{array}{l}\text { Incident knee pain }(24 \%) \text { and } \\
\text { incident severe knee pain }(11 \%)\end{array}$ & $\begin{array}{l}\text { Age, sex, deprivation, } \\
\text { anxiety, depression, } \\
\text { previous knee injury, } \\
\text { widespread pain }\end{array}$ & $\begin{array}{l}\text { For moderate overweight and obesity risk on incident } \\
\text { knee pain was } 1.08(0 \cdot 89,1 \cdot 32) \text { and } 1 \cdot 26(0.95,1.61) \\
\text { and on incident severe knee pain was } 1.53(1.03,2 \cdot 26) \\
\text { and } 2 \cdot 79(1 \cdot 75,4 \cdot 40) \text { (among those without knee pain } \\
\text { at baseline) }\end{array}$ \\
\hline \multicolumn{5}{|l|}{ Case-control studies } \\
\hline $\begin{array}{l}\text { Oliveria et al. } \\
(1999)^{(6)}\end{array}$ & $\begin{array}{l}\text { 1. Woman of the Fallon Community } \\
\text { Health Plan (USA) aged } 20-89 \\
\text { years with knee OA, } n 68 \\
\text { 2. Matched by closest date of birth, } \\
n 68\end{array}$ & $\begin{array}{l}\text { OA based on X-ray plus symptoms } \\
\text { occurring at the time of, or up to } 1 \\
\text { year before, the X-ray }\end{array}$ & $\begin{array}{l}\text { Height, smoking, HRT, } \\
\text { use of medical } \\
\text { services }\end{array}$ & $\begin{array}{l}\mathrm{BMI} \leq 25 \cdot 5: \mathrm{OR}=1.0(\mathrm{ref}) \\
25 \cdot 5<\mathrm{BMI} \leq 30 \cdot 0: \mathrm{OR}=3 \cdot 8(1 \cdot 2,12 \cdot 1) \\
\mathrm{BMI}>30 \cdot 0: \mathrm{OR}=9 \cdot 3(2 \cdot 4,35 \cdot 6)\end{array}$ \\
\hline $\begin{array}{l}\text { Coggon et al. } \\
(2001)^{(5)}\end{array}$ & $\begin{array}{l}\text { 1. Residents of } 3 \text { districts of England, } \\
\text { placed on waiting list for TKR, aged } \\
>45 \text { years, } n 525 \\
\text { 2. Matched by age, sex and family } \\
\text { practitioner, not undergone TKR, } \\
\text { aged }>45 \text { years, } n 525\end{array}$ & $\begin{array}{l}\text { Primaire } \mathrm{OA} \text { based on radiography, } \\
\text { grade } 1-4\end{array}$ & & $\begin{array}{l}20 \cdot 0>\mathrm{BMI} \leq 24 \cdot 9: \mathrm{OR}=1.0(\mathrm{ref}) \\
25 \cdot 0<\mathrm{BMI} \leq 29 \cdot 9: \mathrm{OR}=2 \cdot 5(1 \cdot 8,3 \cdot 6) \\
30 \cdot 0<\mathrm{BMl} \leq 35 \cdot 9: \mathrm{OR}=6.8(4 \cdot 4,10 \cdot 5) \\
36 \cdot 0<\mathrm{BMl}: \mathrm{OR}=13 \cdot 6(5 \cdot 1,36 \cdot 2)\end{array}$ \\
\hline $\begin{array}{l}\text { Holmberg et al. } \\
(2005)^{(27)}\end{array}$ & $\begin{array}{l}\text { 1. Population south of Sweden aged } \\
>70 \text { years with knee OA, } n 825 \\
\text { 2. Matched by age, sex and county, } \\
n 825\end{array}$ & $\begin{array}{l}\text { X-ray reports, knee surgery in past or } \\
\text { evaluated OA as advanced, severe } \\
\text { or moderate }\end{array}$ & $\begin{array}{l}\text { Hereditary, smoking, } \\
\text { knee injuries, } \\
\text { physical activity }\end{array}$ & $\begin{array}{l}23>\mathrm{BMl}: \mathrm{OR}=1 \cdot 0(\mathrm{ref}) \\
23 \leq \mathrm{BMl}<25: \mathrm{OR}=2 \cdot 3(1 \cdot 4,3 \cdot 8) \\
30 \leq \mathrm{BMl}: \mathrm{OR}=10 \cdot 8(6 \cdot 5,18 \cdot 0) \\
25 \leq \mathrm{BMl}<28: \mathrm{OR}=3 \cdot 8(2 \cdot 4,6 \cdot 1) \\
28 \leq \mathrm{BMl}<30: \mathrm{OR}=5 \cdot 3(3 \cdot 1,8 \cdot 9)\end{array}$ \\
\hline
\end{tabular}

NHANES I, First National Health and Nutrition Examination Survey; SWAN, Study of Women's health Across the Nation; TKR, total knee replacement; prev, prevalence; HRT, hormone replacement therapy; VAS, visual

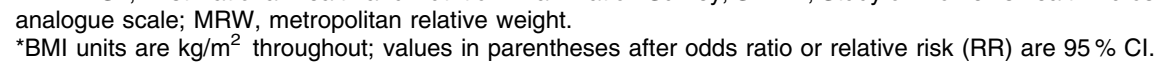


its progression. Messier et al. ${ }^{(39)}$ indicated that each pound $(\sim 0.5 \mathrm{~kg}$ ) of weight loss will result in a fourfold reduction in the load exerted on the knee per step during daily activities. Zamboni et al. ${ }^{(38)}$ also suggested that even small amounts of weight loss might be beneficial. Weight loss can be reached by a combination of physical activity and dietary weight loss. Both must be dosed moderately to provide better overall improvements in self-reported measures of function and pain and in performance measures of mobility ${ }^{(40)}$. In addition, weight loss has been reported to improve mobility-related self-efficacy ${ }^{(41)}$. These results also show that among those with OA, positive effects of weight loss can be found in terms of less disability, better quality of life and reduced health-care costs.

To explore the public health importance of the association of overweight and obesity with health problems of the lower extremities, we can also estimate the population-attributable risk (PAR): around $28 \%$ of OA of the hip or knee is estimated to be attributed to overweight and almost $10 \%$ to obesity in the present population. For the calculation of PAR, valid estimates for both the relative risks and the prevalences of overweight and obesity are needed ${ }^{(42)}$. Using the OR as an estimation of the relative risk is limited by two factors: (i) calculating the PAR implies causality of the association studied, but the association is based on a cross-sectional survey; and (ii) the OR is generally not a good estimation of the relative risk in cases where the rare disease assumption is not met, although most outcome variables were lower than 20\%. With these limitations the estimated PAR should be interpreted with caution, but the OR we used in the PAR calculation was of the same order of magnitude as the relative risk estimates published in the literature and are even in the lower part of the range. This would suggest that our estimated PAR is an underestimation rather than an overestimation. The percentages of overweight and obese participants we used in the PAR estimation are similar to those presented in other Dutch studies ${ }^{(8,9)}$. Although probably being underestimated, our PAR estimations are similar to those reported by others. Felson et $a l^{(31)}$ reported a potential theoretical reduction in the incidence of hip OA of $26 \%$ by eliminating obesity. Both Felson et $a l^{(31)}$ and Hochberg et $a l^{(7)}$ estimated that 26-52\% of knee OA could be prevented by eliminating obesity. Coggon et al. ${ }^{(5)}$ calculated a theoretical reduction of $57 \%$ of total knee replacements if weight in the total population could be reduced to bring BMI in the normal range. Leveille et $_{\text {al }}{ }^{(43)}$ estimated that $25.9 \%$ of self-reported physician-based diagnoses of arthritis could be attributed to overweight and obesity in the most recent wave (1999-2002) of the US National Health and Nutrition Examination Survey.

The present study has some methodological limitations. First, the DMC3 study relies on self-reported data. These data could be influenced by reporting biases of various sorts. It is known that participants, especially the obese, tend to underestimate their weight. Moreover, participants tend to overestimate their height ${ }^{(35)}$. This could lead to an attenuated relationship between BMI and health outcomes.

Second, like other population-based studies in The Netherlands, the DMC3 study also has a relative high non-response ${ }^{(44)}$. However, respondents and non-respondents did not differ in general characteristics, such as marital status, sex, age and region of living, from persons on the population register ${ }^{(13)}$. Only the group who is unmarried or divorced was slightly under-represented. We also compared the response to the DMC3 study with an interview survey carried out in The Netherlands at the same time; the differences were also small for characteristics such as work status, several chronic conditions, and health determinants like smoking, BMI and utilization of health-care services ${ }^{(13)}$. In addition, for the prevalence of musculoskeletal pain (and maybe also OA) it is suspected that the figures are slightly overestimated: late responders had slightly lower rates than early responders and a specific study among 729 non-responders showed slightly lower period prevalences but similar point prevalences of musculoskeletal pain $^{(12)}$.

Another limitation of the current study is that disability was assessed solely on the basis of a global measure, disability in mobility, as measured by the EQ-5D. Future studies should include more detailed data on disability because overweight seems to have an impact. Moreover, the case definition of self-reported OA might include some persons with injuries rather than arthritis. Finally, because of the cross-sectional design, we could not determine causality. It is possible that the risk factor of overweight develops or changes in prevalence after the onset of OA. It is also impossible to determine whether overweight participants with disability in mobility became overweight before or after the onset of disability.

The results of the present study confirm that, within the Dutch population aged $>25$ years, overweight is a risk factor for health problems of the lower extremities, i.e. OA and/or chronic pain. Overweight and especially obesity are also associated with an increased risk of disability in mobility, both among those with and without OA or chronic pain. With the prevalence of overweight arising at a younger age increasing and with the increasingly ageing population, this is reason for concern and argues for more attention to be paid to preventing overweight. In addition, there is some indication that the association of overweight/obesity with arthritis has become much stronger during the last three decades: Leveille et $a l^{(43)}$ estimated that the PAR for arthritis increased from $7 \cdot 8 \%$ (both overweight and obesity) in 1971-1974 to $25 \cdot 9 \%$ in 1999-2002. The data analysed in the present paper were collected in 1998, a decade ago, and the current prevalences of overweight and obesity might be even greater. The same could also be true for the PAR, as suggested by the trend of Leveille et al. ${ }^{(43)}$, 
and this is an extra reason for concern about the health risks of overweight and obesity. This calls for attention to the development of new longitudinal studies on this topic, because the lifetime exposure of the current young and middle-aged population is very different from that of the same population a few decades ago, and this can imply different (and higher) risks.

In general, it important for professionals who are involved with problems resulting from overweight to realize that the burden of obesity is associated not only with diabetes and CVD but also with OA-related health problems. It cannot be accepted that OA, which is known as a disorder of old age, will in the future be increasingly diagnosed among adolescents, like type 2 diabetes is now ${ }^{(45)}$.

\section{Conclusions}

\section{What this paper adds}

1. It is well known that overweight and in particular obesity are risk factors for osteoarthritis of the lower extremities.

2. The study shows the association between overweight/ obesity and health problems of the lower extremities, taking into account (self-reported) osteoarthritis, pain of the knee or hip, and disability in walking.

3. Among patients with osteoarthritis and chronic pain, both moderate overweight and obesity are associated with disability in walking.

4. Around $25 \%$ of health problems of the lower extremities are estimated to be due to overweight and obesity.

5. With the 'epidemic' of obesity, its impact on osteoarthritis and disability is extra reason for concern.

\section{Policy implications}

1. There is an increasing public health policy awareness of the consequences of the increasing prevalences of overweight and obesity. This is focusing on diabetes and cardiovascular risks.

2. In addition, the risk on health problems of the lower extremities, including osteoarthritis, chronic pain and disability, should be taken into account, which has an effect on the planning of health facilities (e.g. total knee replacement and rehabilitation) and the need for development of preventive interventions.

\section{Acknowledgements}

Sources of funding: The Dutch population-based Musculoskeletal Complaints \& Consequences Cohort (DMC3 study) was supported financially by the Ministry of Health, Welfare and Sport of The Netherlands and the National Institute of Public Health and the Environment. Conflicts of interest: None declared.
Author contributions: A.T. carried out the data analyses, literature review and drafted the paper. T.L.S.V. and H.S.J.P supervised this work. H.S.J.P. designed the original study and the idea for the current analyses. All authors contributed to interpretation of the findings and finalizing the manuscript.

Acknowledgement: The DMC3 study was carried out in collaboration with Statistics Netherlands.

\section{References}

1. Han TS, Tijhuis MA, Lean ME \& Seidell JC (1998) Quality of life in relation to overweight and body fat distribution. $\mathrm{AmJ}$ Public Health 88, 1814-1820.

2. Rissanen AM (2006) The economic and psychosocial consequences of obesity. Ciba Found Symp 201, 194-201.

3. Lievense AM, Bierma-Zeinstra SMA, Verhagen AP, van Baar ME, Verhaar JAN \& Koes BW (2002) Influence of obesity on the development of osteoarthritis of the hip: a systematic review. Rheumatology 41, 1155-1162.

4. Peat G, McCarney R \& Croft P (2002) Knee pain and osteoarthritis in older adults: a review of community burden and current use of primary health care. Ann Rheum Dis 60, 91-97.

5. Coggon D, Reading I, Croft P, McLaren M, Barrett D \& Cooper C (2001) Knee osteoarthritis and obesity. Int J Obes Relat Metab Disord 25, 622-627.

6. Oliveria SA, Felson DT, Cirillo PA, Reed JI \& Walker AM (1999) Body weight, body mass index, and incident symptomatic osteoarthritis of the hand, hip, and knee. Epidemiology 10, 161-166.

7. Hochberg MC, Lethbridge-Cejku M, Scott WW Jr, Reichle R, Plato CC \& Tobin JD (1995) The association of body weight, body fatness and body fat distribution with osteoarthritis of the knee: data from the Baltimore Longitudinal Study of Aging. J Rheumatol 22, 488-493.

8. Gast G-MC, Frenken FJ, Van Leest LA, Wendel-Vos GC \& Bemelmans WJ (2006) Intra-national variation in trends in overweight and leisure time physical activities in The Netherlands since 1980: stratification according to sex, age and urbanisation degree. Int J Obes (Lond) 31, 515-520.

9. Schokker DF, Visscher TLS, Van Baak MA \& Seidell JC (2007) Prevalence of overweight and obesity in The Netherlands. Obes Rev 8, 101-108.

10. Visscher TLS \& Seidell JC (2001) The public health impact of obesity. Annu Rev Public Health 22, 355-375.

11. Picavet HSJ \& Hoeymans N (2002) Physical disability in The Netherlands: prevalence, risk groups and time trends. Public Health 116, 231-237.

12. Picavet HSJ \& Schouten JSAG (2003) Musculoskeletal pain in the Netherlands: prevalences, consequences and risk groups, the DMC(3)study. Pain 102, 167-178.

13. Picavet HSJ (2001) National Health Survey by mail or home interview: effects on response. I Epidemiol Community Health 55, 408-413.

14. Euroqol Group (1990) Euroqol - a new facility for the measurement of health related quality of life. Health Policy 16, 199-208.

15. Picavet HS \& Hoeymans N (2004) Health related quality of life in multiple musculoskeletal diseases: SF-36 and EQ-5D in the DMC3 study. Ann Rheum Dis 63, 723-729.

16. Anderson JJ \& Felson DT (1988) Factors associated with osteoarthritis of the knee in the first national Health and Nutrition Examination Survey (HANES I). Evidence for an association with overweight, race, and physical demands of work. Am J Epidemiol 128, 179-189. 
17. Sowers MF, Hochberg M, Crabbe JP, Muhich A, Crutchfield M \& Updike S (1996) Association of bone mineral density and sex hormone levels with osteoarthritis of the hand and knee in premenopausal women. Am J Epidemiol 143, 38-47.

18. Sowers MF, Lachance L, Hochberg M \& Jamadar D (2000) Radiographically defined osteoarthritis of the hand and knee in young and middle-aged African American and Caucasian women. Osteoarthritis Cartilage 8, 69-77.

19. Cimmino MA, Sarzi-Puttini P, Scarpa R, Caporali R, Parazzini F, Zaninelli A \& Marcolongo R (2005) Clinical presentation of osteoarthritis in general practice: determinants of pain in Italian patients in the AMICA study. Semin Arthritis Rheum 35, Suppl. 1, 17-23.

20. Felson DT, Anderson JJ, Naimark A, Walker AM \& Meenan RF (1988) Obesity and knee osteoarthritis. The Framingham Study. Ann Intern Med 109, 18-24.

21. Manninen P, Riihimaki H, Heliovaara M \& Makela P (1996) Overweight, gender and knee osteoarthritis. Int J Obes Relat Metab Disord 20, 595-597.

22. Felson DT, Zhang Y, Hannan MT, Naimark A, Weissman B, Aliabadi P \& Levy D (1997) Risk factors for incident radiographic knee osteoarthritis in the elderly: the Framingham Study. Arthritis Rheum 40, 728-733.

23. Gelber AC, Hochberg MC, Mead LA, Wang NY, Wigley FM \& Klag MJ (1999) Body mass index in young men and the risk of subsequent knee and hip osteoarthritis. Am J Med 107, 542-548.

24. Miranda H, Viikari-Juntura E, Martikainen R \& Riihimaki H (2002) A prospective study on knee pain and its risk factors. Osteoarthritis Cartilage 10, 623-630.

25. Felson DT, Zhang Y, Anthony JM, Naimark A \& Anderson JJ (1992) Weight loss reduces the risk for symptomatic knee osteoarthritis in women. The Framingham Study. Ann Intern Med 116, 535-539.

26. Jinks C, Jordan K \& Croft P (2006) Disabling knee pain another consequence of obesity: results from a prospective cohort study. BMC Public Health 6, 258.

27. Holmberg S, Thelin A \& Thelin N (2005) Knee osteoarthritis and body mass index: a population-based case-control study. Scand J Rheumatol 34, 59-64.

28. Flugsrud GB, Nordsletten L, Espehaug B, Havelin LI \& Meyer HE (2002) Risk factors for total hip replacement due to primary osteoarthritis: a cohort study in 50,034 persons. Arthritis Rheum 46, 675-682.

29. Flugsrud GB, Nordsletten L, Espehaug B, Havelin LI, Engeland A \& Meyer HE (2006) The impact of body mass index on later total hip arthroplasty for primary osteoarthritis: a cohort study in 1.2 million persons. Arthritis Rheum 54, 802-807.

30. Karlson EW, Mandl LA, Aweh GN, Sangha O, Liang MH \& Grodstein F (2003) Total hip replacement due to osteoarthritis: the importance of age, obesity, and other modifiable risk factors. Am J Med 114, 93-98.
31. Felson DT \& Zhang Y (1998) An update on the epidemiology of knee and hip osteoarthritis with a view to prevention. Arthritis Rheum 41, 1343-1355.

32. Tugwell P, Chambers L, Torrance G, Reynolds D, Wolfson M, Bennett K, Badley E, Jamieson E \& Stock S (1993) The population health impact of arthritis. J Rheumatol 20, 1048-1051

33. O'Reilly SC, Muir KR \& Doherty M (1996) Screening for pain in knee osteoarthritis: which question? Ann Rheum Dis 55, 931-933.

34. Quintana JM, Arostegui I, Escobar A, Lafuente I, Arenaza JC, Garcia I \& Aguirre U (2007) Validation of a screening questionnaire for hip and knee osteoarthritis in old people. BMC Musculoskeletal Dis $\mathbf{8}, 84$.

35. Okoro CA, Hootman JM, Strine TW, Balluz LS \& Mokdad AH (2004) Disability, arthritis, and body weight among adults 45 years and older. Obes Res 12, 854-861.

36. Schouten JSAG, van den Ouweland FA \& Valkenburg HA (1992) A 12 year follow up study in the general population on prognostic factors of cartilage loss in osteoarthritis of the knee. Ann Rheum Dis 51, 932-937.

37. Peltonen M, Lindroos AK \& Torgerson JS (2003) Musculoskeletal pain in the obese: a comparison with a general population and long-term changes after conventional and surgical obesity treatment. Pain 104, 549-557.

38. Zamboni M, Mazzali G, Zoico E, Harris TB, Meigs JB, Di Francesco V, Fantin F, Bissoli L \& Bosello O (2005) Health consequences of obesity in the elderly: a review of four unresolved questions. Int J Obes (Lond) 29, 1011-1029.

39. Messier SP, Gutekunst DJ, Davis C \& DeVita P (2005) Weight loss reduces knee-joint loads in overweight and obese older adults with knee osteoarthritis. Arthritis Rheum 52, 2026-2032.

40. Messier SP, Loeser RF, Miller GD, Morgan TM, Rejeski WJ, Sevick MA, Ettinger WH Jr, Pahor M \& Williamson JD (2004) Exercise and dietary weight loss in overweight and obese older adults with knee osteoarthritis: the Arthritis, Diet, and Activity Promotion Trial. Arthritis Rheum 50, 1501-1510.

41. Focht BC, Rejeski WJ, Ambrosius WT, Katula JA \& Messier SP (2005) Exercise, self-efficacy, and mobility performance in overweight and obese older adults with knee osteoarthritis. Arthritis Rheum 53, 659-665.

42. Rothman KJ \& Greenland S (editors) (1998) Applications of stratified analysis methods. In Modern Epidemiology, 2nd ed., pp. 281-301. Philadelphia, PA: Lippincott-Raven.

43. Leveille SG, Wee CC \& Iezzoni LI (2005) Trends in obesity and arthritis among baby boomers and their predecessors, 1971-2002. Am J Public Health 95, 1607-1613.

44. Hupkens CL, van den Berg J \& van der Zee J (1999) National health interview surveys in Europe: an overview. Health Policy 47, 145-168.

45. Rosenbloom AL, Joe JR, Young RS \& Winter WE (1999) Emerging epidemic of type 2 diabetes in youth. Diabetes Care 22, 345-354. 